\title{
Does Leverage, Dividend Per Share, and Cash Flow Volatility Affect Hedging Decisions?: An Empirical Study on Listed Manufacturing Companies
}

\author{
Nikke Yusnita Mahardini \\ Faculty of Economic and Business \\ Universitas Serang Raya \\ Neneng Sri Suprihatin \\ Faculty of Economic and Business \\ Universitas Serang Raya \\ Fanny Nurzamzami \\ Faculty of Economic and Business \\ Universitas Serang Raya
}

\begin{abstract}
The purpose of this study is to examine the effect of leverage, dividend per share, cash flow volatility on the hedging decision. This study uses secondary data of financial statements or annual reports published in the Indonesia Stock Exchange (IDX). The population in this study is manufacturing companies listed on the Indonesia Stock Exchange (IDX) in the period 2015-2018. Purposive sampling technique is adopted in determining the sample of the study. Fourteen listed manufacturing companies are involved in this study. The method of data analysis used is the logistic regression method. The results of the study indicate that leverage and dividend per share have a significant effect on hedging decisions. Meanwhile, Cash flow volatility has no significant effect on hedging decisions.
\end{abstract}

Keywords: leverage; dividend per share; cash flow volatility; hedging decisions.

\section{Introduction}

A Multinational Company (MNC) not only conducts transactions in cash that can cause receivables and debts in various forms of foreign exchange but can also experience gains or losses caused by the exchange rate of foreign currencies. Multiple countries will evaluate foreign currencies using a concept, namely the exchange rate (Hanafi \& Halim, 2015). The exchange rate of a currency is how much money must be paid to obtain foreign currency. Unbalanced supply and demand will create fluctuations in exchange rates and create exchange rate risk (Griffin \& Pustay, 2015). In multinational companies, indirectly or directly, will inevitably be affected by activity, namely exports and imports, where this can pose a risk caused by fluctuations in foreign exchange.
One way to minimize financial risk is by hedging mechanisms (Djojosoedarso, 1999). Hedging is a strategy created to reduce the emergence of unexpected business risks, in addition to the possibility of obtaining profits from such investments (Brigham \& Houston, 2001). Hedging activities can be carried out using derivative instruments, and derivatives are contractual agreements between two parties to sell and buy several goods (both commodities and securities) on a specific date in the future at an agreed price at present. Hedging with foreign exchange derivative instruments is very useful for companies that conduct transactions using foreign currencies. It can reduce the possibility of bankruptcy, allow companies to get credit from creditors more easily, establish better cooperation with suppliers, and allow companies to get loans at lower interest rates (due to the perceived risk of smaller lenders). Hedging can also enable 
companies to predict future cash expenditures and receipts more accurately to enhance the quality of cash budgeting decisions (Zhu, 2011).

The application of hedging itself is still a matter of controversy. Investors often feel suspicious when managers apply business risk hedging to a company. The reason behind implementing hedging is to prevent bankruptcy so that managers do not lose their jobs. The application of hedging itself requires a fee, so managers are considered to be using company funds to protect their work (Brigham $\&$ Houston, 2001). Besides, every investor has a well-diversified investment portfolio and can avoid any risk so that investors feel no need to bear the costs of hedging for certain risks. However, there are several legitimate reasons why companies must hedge, namely: better debt and cost decisions, smoother budget funding, less extreme cases of poor financial performance, better comparative advantage in hedging, and enabling companies to be in lower tax range (Megawati, Wiagustini, \& Artini, 2016).

The hedging decision used by internal factors is leverage, dividend per share, and cash flow volatility. Leverage explains that a high ratio shows that companies use high debt, which means it can increase profitability, but on the other hand, it also increases risk. With higher risk, companies need to hedge to reduce the adverse effects of these risks on the company (Clark, Judge, \& Ngai, 2006); (Bartram, Brown, \& Fehle, 2009). The next internal factor is the Dividend Per Share (DPS). Dividend per share is a ratio that measures the percentage of company profits that can be paid to shareholders or shareholders in cash. Dividend payments affect hedging decisions. It will also affect shareholders in making decisions in internal company actions with international trade transactions and in investing because the changes will provide important information to find out how much the return will be received in the future. The next internal factor is cash flow volatility. This factor indicates that the uncertainty of the business income is very high; the change has the potential to face financial risks, such as bankruptcy costs. Companies with high cash flow volatility have a greater incentive to take advantage of hedging policies with derivative instruments. Cash flow within the company itself is affected by changes in exchange rates and the company's operational activities (Ameer, 2014).

Based on the explanation mentioned above, the research questions as follows: 1) does leverage proxies by debt ratio have a significant effect on hedging decisions?; 2) does leverage proxies by Debt to Equity Ratio significant effect on hedging decision?; 3) does dividend per share have a significant effect on hedging decisions?; 4) does cash flow volatility have a significant effect on hedging decisions?. The purpose of this study is to examine the impact leverage, which is proxies by debt ratio and Debt to Equity Ratio, dividend per share, and cash flow volatility on hedging decisions.

\section{Literature Review and Hypothesis Development}

\section{Hedging}

Hedging can be interpreted as an investment explicitly made to reduce or negate risk on another venture. Hedging is a strategy created to minimize the emergence of business risks that are not unexpected, in addition to the possibility of obtaining profits from such investments (Brigham \& Houston, 2001). Hedging activities can be carried out using derivative instruments. Derivative instruments can group into several types, namely: options, forward, futures, and swap. An option is a contract or agreement that gives the holder the right to buy (or sell) an asset at a predetermined price within a specific period. Forward contracts are contracts for the supply of commodities, foreign currencies, or financial instruments at a price determined at present with delivery and settlement at a specific date in the future (Horne, C, \& Wachowicz, 2007). A futures contract is an agreement to buy or sell an asset for a certain period in the future with certainty of the price agreed upon in advance. A swap contract is two parties that agree to exchange something and have an obligation to make some payments (Brigham \& Houston, 2001).

\section{Leverage}

Leverage ratio is a ratio that measures the extent to which a company's ability to use 
funding through debt (financial leverage) (Brigham \& Houston, 2001). There are two types of leverage ratios, namely the Debt Ratio, and Debt to Equity Ratio. The debt ratio reflects how much assets are financed by debt or how much the company's debt affects the management of assets. The higher the debt ratio, the lower the control by ordinary shareholders and vice versa. Meanwhile, Debt to Equity Ratio (DER) reflects the company's ability to fulfill its obligations as indicated by some part of its capital or equity used to pay debts. The higher Debt to Equity Ratio (DER) shows the composition of total debt (both short and long term) is greater than the own total capital so that the higher the company's burden on external parties (creditors) (Horne et al., 2007).

\section{Dividend Per Share (DPS)}

Dividend per share (DPS) is the amount of dividend distribution that will be distributed to shareholders after compared with the weighted average of ordinary shares outstanding (Irawati, 2006). A high DPR shows how much a company pays its dividends to shareholders. The DPR determines the amount of profit that can retain in a company that is payable to shareholders. High dividend payments will reduce the proportion of their capital, so companies tend to increase debt in financing their investments.

\section{Cash Flow Volatility}

The uncertainty of the operating environment can assess them through cash flow volatility. PSAK No. 2 discloses cash flow statements can provide information that allows users to evaluate changes in the entity's net assets, financial structure, and the company's ability to influence the amount of cash flow in the context of the uncertain operating environment. Cash receipts from future contracts, forward contracts, option contacts, and swap contracts, except if the contract is held for trading purposes and can trading, or if the payment is classifying a financing activity. An agreement intending to hedge the cash flow position, hence the cash flow from the contract classified in the same manner as cash flow from the hedged position.

\section{Leverage and Hedging Decisions}

Leverage is a ratio that shows a company's ability to meet all financial obligations if the company at that time was liquidating. Companies that have transaction exposures will have debt denominated in foreign currencies (US Dollars) so that there is a risk of fluctuations in currency exchange rates when the rupiah depreciates/weakens against US Dollars. There will be an increase in the debt value that can harm companies in the effort to fulfill obligations the debt (Guniarti, 2014). Therefore, the higher the company's leverage, the company needs to do risk management to reduce these risks by hedging activities. So, the higher the company's advantage, the greater the hedging actions were taken by management to mitigate here risks (Nuzul \& Lautania, 2015).

Previous studies suggest that leverage proxies by debt ratio significantly influence the prediction of the probability of hedging activity (Guniarti, 2014); (Nuzul \& Lautania, 2015); (Ameer, 2014). Furthermore, leverage with a proxy for Debt to Equity Ratio shows a significant positive effect on hedging decisions (Ariani \& Sudiartha, 2017); (Widyagocal \& Lestari, 2016). Therefore, the hypothesis is formulated as follows:

Hypothesis 1a: Leverage proxies by debt ratio has a significant effect on hedging decisions.

Hypothesis 1b: Leverage proxies by Debt to Equity Ratio has a significant effect on hedging decisions

\section{Dividend Per Share and Hedging Decisions}

The increase in the number of dividends per share (DPS) reflects the company's performance in producing profits well enough to be considered attractive to investors to invest part of their funds in the form of shares in the company. Research conducted by Chaudhry, Mehmood, \& Mehmood (2014) results that the dividend per share has a significant positive effect on hedge decisions. The amount of dividends to be paid is greatly influenced-by the size of the profit position in a company, and this will affect shareholders' investment decision making. The company must always maintain the opinion of its financial statements so that it will show 
investor confidence in the company's ability to pay the promised dividends. If the number of shares outstanding increases, then cash dividend income per share will be received by ordinary shareholders, also getting more significant. Therefore, the hypothesis is formulated as follows:

Hypothesis 2: Dividends per share has a significant effect on hedging decisions

\section{Cash Flow Volatility and Hedging Decisions}

Cash flow volatility indicates that the uncertainty of business income is very high; the change has the potential to face financial risks, such as bankruptcy costs. The higher the volatility, the higher the company's decision to hedge (Ameer, 2014). The uncertainty of exchange rates on future cash flows causes the company needs to have risk management to secure its cash from bankruptcy. Companies that have a high level of cash flow volatility have a greater incentive to take advantage of hedging policies with derivative instruments. Cash flow within the company itself is affected by changes in exchange rates as well as by the company's operational activities (Ameer, 2014). Goklas \& Wahyudi (2016) stated that cash flow volatility effect on hedging decisions. Therefore, the hypothesis is formulated as follows:

Hypothesis 3: Cash flow volatility has a significant effect on hedging decisions

\section{Methodology}

\section{Design, Data, And Sample}

This research uses quantitative research methods with causality design. The type of data source used is secondary data, namely the financial statements of various industrial sector manufacturing companies listed on the Indonesia Stock Exchange for 2015-2018. The population in this study is multiple industrial sector manufacturing companies listed on the Indonesia Stock Exchange in the 2015-2018 period. The number of samples determined during the observation period was 14 companies with 54 annual report samples.

\section{Model Analysis and Measurement}

This study uses logistic regression analysis techniques. With the equation model as follows:

$\operatorname{Ln} \frac{P}{1-p}=b_{0}+b_{1} X_{1}+b_{2} X_{2}+b_{3} X_{3}+b_{4} X_{4}$

Hedging is an investment made specifically to reduce or eliminate the risk of another investment. The indicators used to assess hedging are forward contracts, futures contracts, option contracts, and swap contracts. Measurements utilize a dummy variable with a nominal scale where one $=$ doing hedging, $0=$ not doing hedging..

Leverage is proxies by Debt Ratio and Debt to Equity Ratio. Debt Ratio is a debt ratio used to measure the ratio between total debt to total assets (Kasmir, 2010). Debt Ratio is measuring by a ratio scale that uses the following formula:

Debt ratio $=\frac{\text { Total Liabilities }}{\text { Total Asset }}$

Debt to Equity Ratio is the ratio used to assess liability with equity. This ratio is useful to know the number of funds provided by the borrower (the creditor) with the owner of the company. Debt to Equity Ratio measures by a ratio scale that uses the following formula:

$$
D E R=\frac{\text { Total Liabilities }}{\text { Total Equity }}
$$

Dividend per share is a dividend paid per share of company shares. Dividend per share measures by a ratio scale that uses the following formula:

$$
\text { DPS }=\frac{\text { Dividend }}{\text { number of share outstanding }}
$$

Cash flow volatility (CFV) is one measure of a company's business risk that marks the possibility of a company facing financial difficulties (Memon et al., 2017). Cash flow volatility is measuring by a ratio scale which is the division between the standard deviation of operating cash flow and total assets, mathematically formulated as follows: 
$C F V=\frac{\sigma(C F O)_{j t}}{\text { Total Asset }_{j t}}$

$\mathrm{CFO}=$ Operating cash flow of the company $\mathrm{j}$ year $\mathrm{t}$

Total Assets = Total Assets of the Company $\mathrm{j}$ year $\mathrm{t}$

\section{Results}

Descriptive Statistical Analysis

Descriptive statistical analysis provides an overview of the data and data dissemination used for each research variable. The following is a descriptive statistical table in this study.

Table 1. Descriptive Statistical

\begin{tabular}{llrrrr}
\hline & N & \multicolumn{1}{c}{ Min } & \multicolumn{1}{c}{ Max } & \multicolumn{1}{c}{ Mean } & Std. Deviation \\
\hline Cash Flow Volatility & 56 & $-0,07$ & 0,26 & 0,0645 & 0,06988 \\
Debt Ratio & 56 & 0,12 & 0,73 & 0,3888 & 0,15618 \\
Hedging decisions & 56 & 0 & 1 & 0,50 & 0,505 \\
Debt to Equity Ratio & 56 & 0,13 & 2,69 & 0,7709 & 0,62056 \\
Dividen Per Share & 56 & 0,00 & 2520,04 & 189,1414 & 509,30674 \\
Valid N (listwise) & 56 & & & & \\
\hline
\end{tabular}

Based on information in table 1 above shows that the degree of spread or index of distribution of the company's cash flow distribution is indicated by the value of cash flow volatility between -0.07 to 0.26 . This value also shows that various movements occur from one period to another in the observed data. The maximum Debt Ratio value of 0.73 times or $73 \%$ shows that $73 \%$ of the company's assets are financed by debt and the remaining $27 \%$ by capital. Based on information in the average value of Debt Ratio that is equal to 0.3888 or $38.88 \%$, the company with the highest Debt Ratio value will increasingly have the risk that the company may not be able to pay off its obligations. This average value shows that the sample company has a good Debt Ratio with a value of less than 0.5 .

Based on descriptive statistical tables show that seven companies make hedging decisions, and seven other companies do not make hedging decisions. The maximum Debt to Equity Ratio (DER) value is well above the average of 2.69. It shows that the company with the highest DER value has a debt of 2.69 times the total capital (2.69: 1). The highest DER value (which calculates all liabilities) of 2.69 indicates an unhealthy company. The maximum Dividend Per Share value of 2,520.04 is part of the profit given to shareholders whose amount is proportional to the number of shares owned.

\section{Partial Testing (Wald Test)}

The significance test uses the Wald test to determine whether the independent variable influences the dependent variable in the logistic regression model. Following is the Wald Test table in this study.

Table 2. Wald Test

\begin{tabular}{clcccccr}
\hline & & B & SE. & Wald & df & Sig. & Exp(B) \\
\hline Step & DR & 6,388 & 7,706 & 4,523 & 1 & 0,033 & 0,000 \\
$1^{\text {a }}$ & DER & 5,941 & 2,558 & 5,395 & 1 & 0,020 & 380,277 \\
& DPS & 0,002 & 0,001 & 2,875 & 1 & 0,090 & 1,002 \\
& CFV & 7,871 & 4,428 & 3,160 & 1 & 0,075 & 2620,880 \\
& Constant & 1,217 & 1,379 & 0,779 & 1 & 0,377 & 3,377 \\
\hline
\end{tabular}


This study uses significance at $\alpha=5 \%$ level. Based on table 2, the logistical equations that are formed are:

$$
\begin{gathered}
\text { Hedging }=1,217+6,388(D R)+ \\
5,941(D E R)+0,002(D P S)+7,871(C F V) .
\end{gathered}
$$

The logistic regression test results show that the Leverage variable, which is proxies by the debt ratio has a Wald value of 4.523 with a significance value of 0.033 . The significance value generated by the Debt ratio $<0.05$ means that the debt ratio affects the hedging decision or the first alternative hypothesis proposed is supported.

The Leverage variable, which is proxies by the Debt to Equity Ratio, has a Wald value of 5.395 with a significance value of 0.020 . The resulting significance value DER $<0.05$ means that the Debt to Equity Ratio affects the hedging decision or the second alternative hypothesis proposed is supported. The dividend per share variable has a Wald value of 2.875 , with a significance value of 0.090 . The significance value produced by DPS $>0.05$ means that dividend per share does not affect hedging decisions, or the proposed third alternative hypothesis is not supported. Variable cash flow volatility has a Wald value of 0.779 , with a significance value of 0.377 . The significance value produced by CFV> 0.05 means that cash flow volatility does not affect the Hedging Decision of the fourth alternative hypothesis proposes is not supported.

\section{Discussion}

\section{Debt Ratio and Hedging}

Based on the test results show that the first hypothesis (H1a), which states that the leverage proxies by the debt ratio have a significant effect on hedging decisions, is supported. The debt ratio in a company will be followed by company management actions to do hedging activities. It is because the probability of companies heading to financial difficulties can be avoided through hedging. Because hedging can protect the variability of a company's future cash flows from market risk. The results of this study are in line with research by Nuzul \& Lautania (2015); Guniarti (2014); Clark et al. (2006).

\section{Debt to Equity Ratio and Hedging}

Based on the test results show that the second hypothesis $\left(\mathrm{H}_{1 \mathrm{~b}}\right)$, which states that leverage is proxies by the Debt to Equity Ratio has a significant effect. Debt to Equity Ratio shows the comparison between the debt held by the company and its capital. The higher the value of the company's Debt to Equity Ratio means, the higher the percentage of the company's debt compared to its wealth. It reflects the increased risk of the company because of the risk borne by the company. This risk can be magnified because sometimes the debt held is not only using the Indonesian currency, but also foreign currencies. It can affect the company is paying its debt because there is a risk of exchange rate fluctuations. The management of exchange rate fluctuation risks can be done through hedging policies. This study's results are in line with research by Bodroastuti, Paranita, \& Lia (2019) and Megawati, Wiagustini, \& Artini (2016).

\section{Dividend Per Share and Hedging}

The third hypothesis $\left(\mathrm{H}_{2}\right)$, which states that dividend per share has a significant effect on hedging decisions, was not supported. These conditions indicate that the dividend per share does not affect the hedging decisions of manufacturing companies. This test results suggest that the rise and fall of the DPS value cannot influence the decision to hedge the company. This study's conclusions relate to the theory that explains that derivative instruments that affect the hedging choice of an option protect their owners from unwanted price movements or levels while allowing their holders to take advantage of the desired changes. Option holders and option publishers are in very different positions. It means that the decision to make hedging is not on the movement desired by shareholders but on the internal company, which is influenced by various things, including accounting calculations. It will also affect shareholders in making decisions in taking the company's civil actions with international trade transactions and making investments. Amendments will provide valuable information by issuing company financial statements, which are a form of corporate responsibility to shareholders (investors). 
The results of this study are by research conducted by Ameer (2014) that there is no significant relationship between hedging. It ensures that the company has a sufficiently good internal investment expenditure or external funding. The amount of dividends to be paid is greatly influenced by the size of the company's profit position. It will affect shareholders in making investment decisions because the company must always maintain the opinion of its financial statements to show investor confidence in the company's ability to pay the promised dividends. If the number of shares outstanding increases, then cash dividend income per share will be received by ordinary shareholders, also getting more significant. The high business risk faced by an entity or business entity will be anticipated with a low payment policy. It can be used to avoid cutting dividends in the future. The allocation of earnings on retained earnings can be used for further investment.

\section{Cash Flow Volatility and Hedging Decisions}

The fourth hypothesis (H3), which states that cash flow volatility has a significant effect on hedging decisions, was not supported. These conditions indicate that cash flow volatility does not affect hedging decisions in manufacturing companies in various industry sectors listed on the Indonesia Stock Exchange in 2015 - 2018. The rise and fall of CFV cannot influence hedging decisions to determine the company's internal policies. The results of this study are consistent with research conducted by Ameer (2014), which states that the level of a company whose operating cash flow is not affected by changes in exchange rates must depend on the nature of its activities, such as the level of exports and import activities. Involvement in foreign market operations with competing currencies and the international market output shows that higher operational activities and foreign sales will lead to the use of foreign currency derivatives against hedging decisions.

Companies with foreign sales are more likely to use derivatives to protect future operating cash flows in foreign currencies that occur due to exchange rate movements. The results of the insignificant research of cash flow volatility are caused by companies included in the sample company that has negative cash flow volatility, which means there are problems in the company. The diversity of each company's volatility is very different because some have sharp volatility, while other companies have cash flow volatility that is not so sharp.

The risk of irregularities in cash flow due to fluctuations in currency exchange rates, companies can take a strategy of hedging. The existence of debt will control excessive use of free cash flow by management so that manufacturing companies with a variety of foreign transactions are objects of the right choice. It is because manufacturing companies have significant fixed assets in which accounting policies are needed. The various possibilities that occur in the company can affect the existence of cash flow irregularities or problems in the company. It can make the company's operating cash flow does not affect the company's internal decisions through accounting policies that have been created.

\section{Conclusion}

Based on data analysis with logistic regression, the following conclusions can be drawn: 1) leverage ratio proxies by the debt ratio has a significant effect on hedging decision; 2) leverage ratio proxies by the Debt to Equity Ratio has a significant effect on hedging decision; 3 ) dividend per share ratio does not significantly affect on hedging decisions; 4) cash flow volatility ratio does not significantly affect on hedging decisions.

The limitation of this study is that the sample used is only limited to financial statements for the period 2015 - 2018and only in manufacturing companies in the miscellaneous sector. The leverage ratio used is only limited to debt ratio and Debt to Equity Ratio without using other leverage ratios. Based on these limitations, the suggestion for further research is to extend the period of observation and include manufacturing companies with other sub-sectors. Therefore, the results can be more generalized. In the next study, their searcher also suggested the use of different data analysis tests, and the use of other variables, for example, growth opportunity and other leverage ratios. 


\section{Reference}

Ameer, R. (2014). Determinants of Corporate Hedging Practices in Malaysia. (March 2010). https://doi.org/10.5539/ibr.v3n2p120

Ariani, N. N. N., \& Sudiartha, G. M. (2017). Pengaruh Leverage, Profitabilitas, dan Likuiditas terhadap Keputusan Hedging Perusahaan Sektor Pertambangan Di Bursa Efek Indonesia. E-Jurnal Manajemen Unud, 6(1), 347-374.

Bartram, S. M., Brown, G. W., \& Fehle, F. R. (2009). International Evidence on Financial Derivatives Usage. Financial Management, 38(1), 185-2016.

Bodroastuti, T., Paranita, E. S., \& Lia, R. (2019). Faktor-Faktor yang Berpengaruh terhadap Kebijakan Hedging Perusahaan di Indonesia. Valid Jurnal Ilmiah, 16(1), 71-84.

Brigham, E. F., \& Houston, J. F. (2001). Manajemen Keuangan (Delapan). Jakarta: Erlangga.

Chaudhry, N. I., Mehmood, M. S., \& Mehmood, A. (2014). Determinants of Corporate Hedging Policies and Derivatives Usage in Risk Management Practices of Non-Financial Firms. Wulfenia Journal, 21(7), 293-310.

Clark, E., Judge, A., \& Ngai, W. S. (2006). The Determinants and Value Effects of Corporate Hedging: An Empirical Study of Hong Kong and Chinese Firms. Paper Studies, Accounting and Finance, Middlesex University, 44(August), 1-41.

Djojosoedarso, S. (1999). Prinsip-Prinsip Manajemen Risiko dan Asuransi. Jakarta: Salemba Empat.

Goklas, F., \& Wahyudi, S. (2016). Kebijakan Heging dan Faktor-Faktor yang Mempengaruhinya (Studi Empiris pada Perusahaan Non Finansial yang Terdaftar di BEI Periode 2012-2014. Diponegoro
Journal of Management, 5(4), 1-14.

Griffin, R., \& Pustay, M. W. (2015). Bisnis Internasioal: Sebuah Perspektif Manajerial (8th ed.). Jakarta: Salemba Empat.

Guniarti, F. (2014). Faktor-Faktor yang Mempegaruhi Aktivitas Hedging dengan Instrumen Derivatif Valuta Asing. 5(1), 64-79.

Hanafi, M., \& Halim, A. (2015). Analisis Laporan Keuangan (Kelima). Yogyakarta: UPP STIM YKPN.

Horne, V., C, J., \& Wachowicz, J. (2007). Prinsip-Prinsip Manajemen Keuangan. Jakarta: Salemba Empat.

Irawati, S. (2006). Manajemen Keuangan. Bandung: Pustaka.

Kasmir. (2010). Analisis Laporan Keuangan (1st ed.). Jakarta: Raja Grafindo Persada.

Megawati, I. A. P., Wiagustini, L. P., \& Artini, L. G. S. (2016). Determinasi Keputusan Hedging pada Perusahaan Manufaktur di Bursa Efek Indonesia. E-Jurnal Ekonomi Dan Bisnis Universitas Udayana, 10(5), 3391-3418.

Nuzul, H., \& Lautania, M. F. (2015). Pengaruh Leverage, Financial Distress dan Growth Options terhadap Aktivitas Hedging Pada Perusahaan Non-Keuangan yang Terdaftar di Bursa Efek Indonesia. Jurnal Dinamika Akuntansi Dan Bisnis, 2(2), 104-113.

Widyagocal, I. G. P. A., \& Lestari, P. V. (2016). Pengaruh Leverage, Growth Opportunities, dan Liquidity terhadap Pengambilan Keputusan Hedging PT. Indosat Tbk. E-Jurnal Manajemen Unud, 5(2), 1282-1308.

Zhu, M. R. (2011). Corporate Hedging, Financial Distress , and Product Market Competition. Working Paper. Austin: University of Texas., (January), 1-56. 